4. HISTORIA DEL DERECHO INDIANO 

Revista de Estudios Histórico-Jurídicos

[Sección Historia del Derecho Indiano]

XXXII (Valparaíso, Chile, 2010)

[pp. 351 - 379]

\title{
LAS PENAS Y LOS CASTIGOS PARA LA IDOLATRÍA APLICADOS \\ EN LAS VISITAS DE IDOLATRÍA EN LIMA DURANTE EL SIGLO XVII*
}

[Penalties and Punishments for Idolatry Applied in Idolatry Extirpators in Lima During the $17^{\text {th }}$ Century]

\author{
Macarena Cordero Fernández** \\ Universidad Adolfo Ibáñez, Santiago de Chile
}

\begin{abstract}
RESUMEN
El sistema punitivo aplicado a los indígenas, judicialmente declarados como apóstatas por las visitas de idolatrías, tuvo una serie de peculiaridades que implicaron la reformulación de la tipología penal y sus finalidades, que fueron diferentes de las consideradas en el orden del Antiguo Régimen. Se produjo, en efecto, una fisura en el sistema punitivo susceptible de ser calificado como modernizante o protomoderno. Ello, porque con base en el estatuto protector indígena y la praxis judicial, se idearon castigos cuyos objetivos debieron adecuarse a la realidad cultural de las poblaciones andinas. Se estatuyó, por ejemplo, la cárcel en el sentido moderno y se descartaron otras por la imposibilidad de ser aplicadas.

Palabras Clave: Idólatras - Visitas de idolatrías - Proporcionalidad de la pena - Pena de cárcel - Estatuto protector del indígena.
\end{abstract}

\begin{abstract}
The punitive system applied to the native people, legally declared as apostates by the idolatry extirpators, had several characteristics that implied the reformulation of the criminal classification and objectives, which were different from the ones considered in the order of the Old Regime. As a matter of fact, a fissure was created in the punitive system, susceptible to be qualified as modernising or post-modern. The aforementioned occurred because, based on the indigenous protector statute and the legal praxis, some punishments were created, objectives of which had to be adjusted to the cultural reality of the Andean populations. For example, jail in the modern sense was established and other punishments were ruled out because it was impossible to apply them.

KEYwORDS: Idolaters - Idolatry extirpators - Proportionality of the criminal sanction - Prison term - Statute of protection of native people.
\end{abstract}

* Este artículo es parte de la investigación elaborada en el marco de la tesis para obtener el grado de Doctor en Historia en la Pontificia Universidad Católica de Chile, dirigida por el profesor René Millar Carvacho.

** Candidata a Doctora en Historia por la Pontificia Universidad Católica de Chile. Profesora del departamento de Historia de la Universidad Adolfo Ibáñez. Dirección postal: Correo electrónico: maria.cordero@uai.cl 


\section{LAS VISITAS DE IDOLATRÍA}

A inicios del siglo XVII, el cura doctrinero Francisco de Ávila descubrió que los indios bautizados de la región de Huarochirí continuaban practicando idolatrías y que, en buenas cuentas, estaba en presencia de apóstatas. Ante tamaño problema decidió que el mal debía atacarse de un modo más eficiente y duradero, y dio origen a las visitas de idolatrías, proceso único que llegó a transformarse en una verdadera institución, equiparable a la inquisición para los españoles, debido al hecho que las visitas de idolatrías, que se desarrollaron a partir de 1607 en las zonas rurales de la diócesis de Lima, fueron constituidas como verdaderos tribunales, cuyo objetivo era investigar y castigar a los apóstatas de la fe.

Por lo anterior, es posible establecer que un tránsito hacia un nuevo orden colonial se empezaba a gestar en las políticas eclesiásticas iniciadas a principios del siglo XVII, que dejaban atrás los años de tolerancia a diversas manifestaciones de los pueblos andinos que no se contrapusieran al dogma cristiano. Así, a partir del siglo XVII se privilegiaba un mayor control religioso sobre esta población y sus dirigentes, quienes eran cuestionados por permitir la pervivencia de las idolatrías.

El problema ocurría, principalmente, en las zonas rurales de la diócesis de Lima, pues en los centros urbanos los indígenas se mostraban como fervientes católicos, que paulatinamente se habían adaptado al sistema de vida hispano, aunque incorporado según sus propias categorías mentales. Sin embargo, a pocos kilómetros de Lima se descubría una realidad diferente y disonante a la de la capital virreinal. Miles de indígenas se encontraban entregados a la idolatría, situación que, para la Iglesia, era del todo inaceptable, puesto que se ponía en peligro la salvación de estas almas y se dejaba en evidencia el fracaso del proceso de evangelización realizado durante décadas.

En coincidencia con la instauración de la ortodoxia católica en el Nuevo Mundo, luego de Trento y de la instalación del Santo Oficio en México y Perú, se dio inicio a un movimiento que tuvo por finalidad suprimir los rebrotes de la idolatría. Así fue que se creó una nueva institución -las visitas de idolatrías-, que se estructuró en dos etapas. Una primera, de carácter judicial represivo, realizada por tribunales itinerantes que tenían por objeto someter a proceso judicial a los idólatras y destruir todo vestigio de la religión pagana. Y una etapa pastoral, dirigida por los sacerdotes jesuitas, a quienes les correspondía acompañar a los visitadores de idolatrías con el fin de afianzar la fe católica entre los indígenas.

Los séquitos extirpadores se diseminaron por la diócesis de Lima con el firme propósito de descubrir la idolatría y restaurar la fe católica entre sus habitantes. La novedad que presentó el sistema no fue la destrucción de la idolatría o la represión de conductas heterodoxas de los indígenas, sino el hecho de someter a proceso judicial a los indios apóstatas de la fe católica, en un contexto en que el Santo Oficio carecía de jurisdicción para poder enjuiciarlos. Lo anterior, significó que aquellos considerados idólatras ya no sólo pecaban gravemente contra la sanidad de la doctrina, sino que arriesgaban ser calificados de delincuentes, pues sus actos podían dar pie para incoar un proceso judicial que finalizaría con una sentencia condenatoria, si correspondía. El apóstata ya no sólo era pecador, sino 
que además, pasaba a ser un peligro para la sociedad colonial, pues con su actuar ponía en jaque el máximo valor jurídico custodiado e impuesto por la Corona y la Iglesia: la fe.

Aún más, el hallazgo realizado por los sacerdotes no estaba circunscrito sólo a la consideración individual "del apóstata", sino que denotaba un "comportamiento social" de los pueblos de indios. Es decir, tras las prácticas y modos de acción que la mayoría de la población ejecutaba había, sin duda, un cierto consenso social indígena de retomar la religión de sus padres, para así mantener su propia identidad y cultura, aunque también transformada por la influencia del catolicismo. Desde esta perspectiva, se justificaba instituir un sistema que pudiera ser eficiente y eficaz en destruir los vestigios de idolatrías que aún eran observables en las zonas rurales y reafirmar el catolicismo.

Frente a la pervivencia de las idolatrías y del proceso de superposición de ritos andinos y católicos, fenómeno que desviaba a los indígenas de la pureza de la fe católica, más la imposibilidad de aplicar la jurisdicción del Santo Oficio en el estamento indígena, los obispos limeños, durante el siglo XVII, consideraron que sobre la base de sus facultades ordinarias, entre ellas la de inquirir, estaban en condiciones de organizar una institución dirigida especialmente a los indios con el objetivo de poner fin a las prácticas y ritos alejados de la ortodoxia: las visitas de idolatrías.

A su vez, la necesidad de crear una nueva institución se debió porque la población y el espacio geográfico donde se implementó era distinto a lo entonces conocido por la Iglesia, cuestión que en definitiva impulsó la formulación de alternativas viables y acordes con la realidad cultural y social andina. Asimismo, esta nueva institución debía contener un sistema normativo acorde a sus destinatarios -los nativos- , lo que implicaba modificar el modelo inquisitorial y el sistema de penas y castigos, en razón del estatuto protector indígena.

Aún más, el sistema antiidolátrico pensado y constituido dio paso a una institucionalidad protomoderna o modernizante, puesto que contempló una serie de garantías a sus destinatarios. Incluso, la práctica judicial de los primeros séquitos extirpadores se estructuró sobre la base del respeto al estatuto protector indígena y sus beneficios, al cual debía ceñirse el sistema de extirpación de idolatrías por la vía judicial y punitiva. Así, a los culpables de idolatrías se les aplicaron penas más leves y reducidas respecto de los condenados por la Inquisición, e incluso con finalidades diversas a las del Antiguo Régimen, lo que es por sí solo un poderoso argumento para sostener que en los Andes se abrió una puerta hacia la transformación e incorporación de nuevos discursos cuyo objeto fue instituir y organizar un sistema de justicia tendiente a resguardar a las partes más débiles frente al aparato estatal, beneficiando a los procesados y sentenciados.

Por lo anterior, es preciso definir si el sistema punitivo observado tenía por fin sólo castigar las prácticas idolátricas, establecer castigos ejemplificadores que desmotivaran futuras transgresiones, o servir de herramienta para convertir a los indígenas acusados.

El objeto nuestro es abordar el sistema punitivo implementado en la extirpación de idolatrías realizada durante el siglo XVII por los tribunales itinerantes, 
en las zonas rurales de la diócesis de Lima. De ello dan cuenta los expedientes de idolatrías conservados en el Archivo Arzobispal de Lima ${ }^{1}$, en virtud de los cuales pretendemos establecer que un nuevo sistema de penalización se implementó, principalmente, porque se debió reformular el sistema contemplado en el Antiguo Régimen, produciéndose una incipiente modernización del mismo.

\section{Penas y CASTigos PARA LA idolatría}

Durante el proceso judicial seguido por los visitadores de idolatrías podía suceder que el reo fuese declarado culpable. De ser tal el caso, se le debía aplicar una pena o castigo. La legislación canónica indiana no realizó una conceptualización ni tipificación ni graduación de la pena; menos aún, elaboró una doctrina relativa a las finalidades de la misma. Por su parte, la legislación penal del Antiguo Régimen tampoco teorizó sobre este concepto, y los pocos que lo hicieron "orientan poco acerca de cómo eran éstas en la ley y en la práctica judicial"”, pues lo pensado por los juristas constituía una cuestión "ideal”, lo que creían que debía ser el sistema penitenciario, el que no se condecía con el sistema represivo aplicado por el sistema judicial de la época.

Cabe preguntarnos ¿̇de qué manera era posible penalizar a una persona declarada judicialmente culpable de idólatra? En virtud del arbitrio judicial con que contaron los foros de justicia del Antiguo Régimen el castigo se determinaba para cada caso concreto, cuestión que conllevaba la indeterminación legal de la pena. Es decir, si distintos sujetos cometían un mismo delito, no había ley alguna que dispusiera cuál era el castigo por ello, y en consecuencia podían variar su proporcionalidad según el criterio del juez que conociese el proceso ${ }^{3}$. Ello también significó que los jueces se constituyesen en co-creadores de derecho al establecer para cada delito una pena.

Con todo, las Partidas definían el concepto de pena y establecían su finalidad, entendida como: "[...] enmienda de pecho o escarmiento que es dado según ley a algunos por los yerros que fizieron" ". Por su parte, Sebastián de Covarrubias señalaba que se entendía por "pena: el castigo que fe da en razon de culpa"s. En otras palabras, se debe entender que la pena fue conceptualizada como el castigo que se daba al delincuente por su actuar dañino.

En el caso que nos ocupa, y al igual que la Inquisición ${ }^{6}$, las penas o castigos

${ }^{1}$ Para el desarrollo del siguiente artículo se revisaron ciento setenta y ocho expedientes de los legajos correspondientes al siglo XVII. De estos expedientes, ciento treinta y siete son inéditos conservados en el Archivo Arzobispal de Lima, en adelante AAL.

${ }^{2}$ Tomás y Valiente, Francisco, El Derecho penal en la Monarquía absoluta. Siglo XVI, XVII y XVIII (Madrid, Tecnos, 1969), p. 353.

${ }^{3}$ En la actualidad la pena debe ser legal, impuesta por ley anterior y vigente en relación a cada delito concreto.

${ }^{4}$ Partida VII,31,1.

${ }^{5}$ Covarrubias Horozco, Sebastián, Tesoro de la lengua castellana o española (Madrid, Luis Sánchez, 1611).

${ }^{6}$ Las visitas de idolatrías tuvieron como modelo la Inquisición. Lo anterior cobra importancia porque quienes organizaron la institución de las visitas de idolatrías no elaboraron una 
impuestos a los delincuentes por los visitadores de idolatrías se fundamentaron en la ofensa infligida a Dios y el gravísimo daño que podían causar tales conductas a la comunidad; por ello es que las penas eran tan severas y rigurosas. Sus principales objetivos o finalidades eran la corrección y enmienda del delincuente. Como señala Tomás y Valiente: "En general se opina que la pena tiene un fin correccional: equilibra el orden y repone la paz tanto en la sociedad como en el alma del delincuente, ya que este castigo expía su culpa"7.

En buenas cuentas, la pena en el Antiguo Régimen tenía un fin correccional y enmendador, que equilibraba el alma del delincuente, puesto que el castigo expiaba sus culpas, en nuestro caso las del idólatra. Más aún si consideramos que el castigo, teóricamente, era una penitencia voluntariamente aceptada por el penitente para la valoración de su alma ${ }^{8}$. Correctivo, además, porque debía servir de escarmiento para toda la sociedad?.

A su vez, al igual que la Inquisición, las penas impuestas por las visitas de idolatrías tuvieron una finalidad ejemplificadora para la sociedad, esto es, provocar por su aplicación al delincuente un temor en los demás miembros de la comunidad, de tal forma que se desincentivaran las acciones que comprendiesen delitos contra la Fe. Se trata, dicho de otro modo, de un castigo ejemplar, utilizando para ello el temor y el miedo, pues mediante ellos era posible lograr que las personas se apartasen del error. Esa situación se ve claramente reflejada en los autos de fe, cuya espectacularidad y publicidad de las penas impresionaban a cualquiera. Asimismo, la pena de azotes, trasquilación o cualquier otra que conllevase la vergüenza pública, impactaban a los indígenas, quienes bajo el sentimiento del miedo y humillación abandonaban, aunque fuese por un tiempo, las prácticas idolátricas.

A su vez, las penas impuestas podían compartir un rasgo utilitarista o una finalidad social, en el sentido de que el castigo inferido no sólo lograse amedrentar e intimidar a los indígenas individualmente, sino que además prestase alguna ventaja o beneficio para la comunidad. Tal es el caso de las penas de prestación de servicios en hospitales o conventos, o la tan temida de galeras impuesta en Lima durante el siglo XVII por el Santo Oficio ${ }^{10}$ y las visitas de idolatrías.

La pena, además, tenía por finalidad reeducar al delincuente. En efecto, no sólo se castigaba, cautelaba, reprimía y ejemplificaba con la aplicación de una pena a una persona, sino que también se buscaba volverlo al seno de la Iglesia.

teoría relativa a la pena, de ahí que nos hemos remitido al sistema inquisitorial para deducir aquellos aspectos no contemplados o analizados por los gestores del nuevo sistema. Para más detalles relativos a la finalidad de la pena en la Inquisición española, véase: GARCía MARín, José María, Magia e Inquisición. Derecho penal y procedimiento inquisitorial en el siglo XVII, en Escudero, Antonio (editor), Perfiles jurídicos de la Inquisición Española (Madrid, Universidad Complutense, 1992), p. 217.

${ }^{7}$ Tomás y Valiente, Francisco, ct. (n. 2), p. 353.

${ }^{8}$ LeA, Henry, Historia de la Inquisición Española (Madrid, Fundación Universitaria Española, 1983), II, p. 611

${ }^{9}$ Foucault, Michel, Vigilar y castigar. Nacimiento de la prisión (Buenos Aires, Siglo Veintiuno, 2004), capítulo II: "Castigar”.

${ }^{10}$ Millar, René, Inquisición y sociedad en el virreinato peruano (Santiago, Pontificia Universidad Católica de Chile, 1997), p. 73. 
De ahí que a muchos idólatras se los sancionó con la obligación de concurrir a la doctrina una cantidad determinada de días; o bien con la realización de trabajos para la comunidad, o ser adoctrinados en la Cárcel de Santa Cruz del Cercado de Lima. Tal objetivo de reeducar y reformar al indígena idólatra llama profundamente la atención, puesto que el sistema de penas aplicado en las Indias era el propio del Antiguo Régimen, es decir, con carácter represivo, ejemplificador y con gran impacto social ${ }^{11}$, tales como: el cepo, los azotes, la horca, el garrote, el sambenito o la pena de destierro. De ahí que nos asombre la existencia de penas diversas con finalidades novedosas respecto de las que comúnmente aplicaban los tribunales reales y canónicos. Más aún, si tomamos en consideración que el sistema penal en Occidente sólo se reformuló en el sentido de establecer penas tendientes a reformar y reeducar al hombre, con carácter más formativo que represivo, a partir de la influencia de la Ilustración y por el impacto que provocaron las reflexiones y críticas al sistema penal de Cesare Beccaria en el "Discurso sobre las penas" de 1792 .

Así pues, la creación a principios del siglo XVII de la Cárcel de Santa Cruz a instancias del arzobispo de Lima Bartolomé Lobo Guerrero y organizada por el jesuita Pablo de Arriaga ${ }^{12}$, constituyó un salto modernizador en el sentido de que se deseó que en ella no sólo estuvieran recluidos y cautelados de por vida los hechiceros y dogmatizadores, verdaderos peligros para la cristiandad, sino también que se los convirtiera y reformara, logrando, de paso, su salvación ${ }^{13}$.

Una vez más, en pos de la protección de los indios y la necesidad de darles un

${ }^{11}$ LEÓn, Marco Antonio, Encierro y corrección. La configuración de un sistema de prisiones en Chile. (1800.1911) (Santiago, Universidad Central, 2003) p. 58, afirma respecto de las finalidades de las penas que: "[...] desde el siglo XVI hasta el siglo XVIII, frente a la espectacularidad de los suplicios, la penalidad estuvo dominada por las necesidades de Estado, ya fuese en lo relativo a disponer de fuerza de trabajo gratuita (las galeras), a manifestar su poder en la comunidad (ejecuciones) o financiar los gastos militares (confiscación de bienes) que se hicieron imprescindibles para solventar la expansión a nuevos territorios”.

${ }^{12}$ Desde el siglo XVI se contempló la necesidad de recluir a los dogmatizadores y hechiceros en un local especial, designándolos con signo distintivo, cuestión que se concretó en la constitución 107 del II Concilio de Lima, ratificado por el III Concilio de Lima. A su vez, las normas conciliares consideraban que estos indígenas debían ser encerrados de por vida. Con todo, las constituciones no contemplaban la finalidad reeducadora de la pena. A su vez, los locales que se crearon para recluir a los indígenas, las más de las veces se trataba de sitios transitorios e improvisados, lo que provocaba la poca o casi nula efectividad de la pena. Para más detalles, véase: Borges Morán, Pedro, Métodos misionales en la cristianización de América. Siglo XVI (Madrid, Consejo Superior de Investigaciones Científicas, 1940), cap. V.

${ }^{13}$ AGI, Lima, 301: "Carta del arzobispo Lobo Guerreo al Rey”, 20 de abril de 1611. Respecto de la cárcel y su evolución, MAYNTZ, Renate, Sociología de la organización (Madrid, Alianza, 1972), p. 18. Señala: “[...] los precursores de la prisión actual fueron, hasta el final de la Edad Media, ante todo, las mazmorras en las plazas fuertes de los señores espirituales y temporales. Si en las ciudades había calabozos para deudores y cárceles municipales, en general era menos corriente la privación de libertad, como pena impuesta por los tribunales, a causa de la violación de las leyes, que las penas corporales y las que recaían sobre la vida y la propiedad [...] al final del siglo XVI se difundieron las prisiones de trabajo [...]. Desde entonces se desarrolló la prisión moderna. Hacia finales del siglo XVIII las prisiones de trabajo fueron reemplazadas por prisiones celulares en las cuales ya no se trabajaba [...]". 
trato más benigno que a los españoles, el sistema se vio forzado a reformularse y modificarse conforme a las exigencias reales y eclesiásticas. No era posible aplicar las penas y objetivos tal como estaban fundamentados jurídica y teológicamente. Se debió introducir un nuevo objetivo que se reconciliara y ajustara al estatuto jurídico protector de los indios. En tal sentido, la Iglesia, pese al temor que tenía a la existencia de opositores a su doctrina y de movimientos heréticos, con respecto a los neófitos del Nuevo Mundo debió flexibilizar su postura y actuar de manera más adaptable, quizás tolerante, pues seguramente sólo de esa forma podía ganar más almas para su causa y conquistar a todos sus habitantes.

De ahí que las penas no sólo tiendan a reprimir y atemorizar a la comunidad, sino que también cumplen con la función de civilizar, pues el primer deber de la Iglesia así como el de la Corona era precisamente captar almas para salvarlas. De haberse aplicado sólo una política abiertamente represiva sobre las conductas idolátricas, ello habría implicado, por una parte, una mayor resistencia por parte de los nativos a los españoles, su Dios y sistema de vida, y por otra, el incumplimiento del primer deber que tenían en tierras indianas tanto la Corona como la Iglesia de evangelizar y cuidar de los indígenas.

A su vez, mediante la pena carcelaria se lograba un vasto control social sobre aquellos indígenas idólatras considerados de mayor peligro para la sociedad. En efecto, mediante la vigilancia y control continuo que se obtenía al interior de la cárcel, era posible reeducar al criminal y reconvertirlo a la fe católica de manera más efectiva ${ }^{14}$. La introducción de la pena carcelaria en sentido moderno, esto es, encierro del criminal con la finalidad de reeducarlo, constituyó un avance en lo relativo al sistema de corrección penitenciario, lo que evidencia un incipiente debate antropológico jurídico de los teóricos en torno de cuestionamientos que el cuerpo social de la época formuló respecto de la utilización de penas humillantes e infamantes a los sectores indígenas.

Por otra parte, y con el solo objetivo de lograr que las finalidades de la pena se cumpliesen, era indispensable la publicidad de la misma. Para ello, era fundamental la realización del auto de fe, acto público por excelencia que daba a conocer a todos los miembros de un pueblo de los delitos de sus integrantes y las respectivas sanciones que se aplicarían. A ello se sumaba el pregonero, quien recorriendo las principales calles y plazas del pueblo, gritaba a viva voz que "fulano de tal" "manifestaua el delito merecedor de aquel castigo ${ }^{15 " .}$

Ahora bien, como ya se ha dicho, las penas no estaban fijadas normativamente en la legislación, fuese penal o eclesiástica. En otras palabras, las penas no estaban impuestas por ley positiva y vigente en relación con cada delito en concreto, sino que, a base del principio de la arbitrariedad judicial que tenía el juez, se iba fijando qué pena se aplicaba una vez que el delincuente resultaba condenado.

Con todo, el visitador de idolatrías debía tener presente a la hora de sancionar a los indígenas que los principios de la legislación indiana contemplaban castigos más leves que los establecidos para los españoles: “[...] minorando en quanto

\footnotetext{
${ }^{14}$ Foucault, Michel, cit. (n. 9).

${ }^{15}$ ARSI Perú, 16: "Carta Annua Lima”, 1660-1662.
} 
puede la de los pacientes, cuya poca capacidad y natural rendiminto les hacia menos culpables, valiéndome para ello de lo que en casos semejantes juntan y resuelven Cateliano Cota y Pedro Caballo"16.

De esta manera se justifica y se explica por qué a los indios se les castigó con penas menos severas que a los españoles por los mismos actos. E incluso más, refleja la condescendencia que muchas veces tuvieron los séquitos extirpadores frente a indígenas relapsos y reincidentes, como: "A la dicha Juana Mayo le compensava y compenso por pena de su culpa y castigo de su delito, el tiempo que a estado presa desde çinco de febrero deste presente año mil seisçientos y sesenta y nueve y la exortava y exorto a que viva de aqui en adelante como buena christiana temerosa de Dios y de su conçiencia frecuentando los sanctos sacramentos con apersevimiento que si volviere a incidir en este delito o semejantes sera castigada con todo rigor y como se hallare convenir en derecho" 17 .

Sumado a lo anterior, se debe tener en cuenta que en muchas ocasiones las penas se vieron rebajadas en atención a que el delincuente había concurrido libremente a confesarse, o bien a la avanzada edad o al mal estado de su salud, entre otras: " [...] con lo qual el dicho señor visitador por ser mui bieja le commuto la pena corporal en que truxese una cruz colgada por insignia de penitenciada [ [...] ]"18.

A contrario sensu, existen casos en que los castigos fueron bastante severos debido, principalmente, a que los indígenas eran relapsos o bien sus actos habían sido de tal gravedad que las autoridades de la época en razón de la arbitrariedad consideraban que la pena debía ser mayor: "[...] condeno al dicho Pedro Sebastián en cien azotes coraça trasquilado el cabello cruz perpetua al cuello y dos años de galeras en las del puerto del Callao [ [...] ]"19.

Lo anterior nos permite concluir que de alguna manera se estableció un criterio no normativo para fijar una cierta proporcionalidad de las penas, lo que sin duda fue promovido por el estatuto jurídico protector de los indígenas y por la práctica judicial de los jueces. En efecto, del corpus documental que existe es factible sostener que los visitadores de idolatrías fijaron criterios no sólo morales (la ofensa a Dios) para establecer una pena, sino que, además, tomaron en cuenta el sexo, edad, estado de salud y la calidad de reincidente o no del acusado de idolatría, entre otras consideraciones. Sumado a ello, establecieron pautas en virtud de las cuales distinguieron, según el daño que podía provocar el delito, la pena respectiva. De ahí que al condenado por dogmatizador, tal vez el delito más peligroso, se le aplicaba la pena más grave que contemplaba la legislación antiidolátrica, esto es, la de encierro en la cárcel, mientras que si un indígena era curandero o simplemente "mochaba sus huacas", se le asignaba una pena más leve, como la de tener que asistir a la doctrina o bien prestar servicios en hospitales.

\footnotetext{
${ }^{16}$ Solórzano y Pereira, Juan de, Política Indiana (Madrid, Biblioteca de Autores Españoles, 1972), II, p. 304.

${ }^{17}$ AAL, leg, VI, exp. 8.

${ }^{18}$ AAL, Leg, IIA, exp. 3. Causa criminal de hechicera contra Maria Caxa Pampay india del pueblo de San Pedro de Carac del ayllo Callan.

${ }^{19}$ AAL, Leg. IIA, exp. 9: "Sentencia de la causa criminal de hechicero de oficio contra Pedro Sebastián, indio del pueblo de San Agustin de Huaquis, provincia de Yauyos”.
} 
La obligación que asistía a las instituciones coloniales de supeditarse al estatuto indígena implicó salvaguardar y establecer mayores garantías a este grupo. Si lo comparamos con el derecho penal dirigido a los otros habitantes indianos, evidentemente se produce una fisura. Al derecho penal, en general, no le importó la proporcionalidad de la pena. Si bien los criterios que predominaron para establecer un castigo fueron los morales, la frecuencia de un mismo delito o el hecho de que determinadas prácticas se calificaran como "plaga social” implicó que la justicia penal no se detuviera a ponderar las penas, ni menos aún a considerar las voces teóricas que intentaban establecer una cierta graduación; por el contrario, en tales situaciones la justicia penal abusó de la pena más grave: la muerte, sin importar si un robo era con o sin violencia, o si simplemente se trataba de un hurto doméstico ${ }^{20}$.

Sin embargo, en los expedientes de idolatrías queda registrada una situación diversa y novedosa que rompe con las prácticas judiciales de la época. Sabemos que la idolatría era el delito más grave. A su vez, que para el siglo XVII quedaba en evidencia el fracaso del proceso evangelizador en las zonas rurales, lo que se manifestaba en la persistencia de múltiples focos idolátricos en las comunidades indígenas. Esta especie de "plaga idolátrica” debía ser perseguida y castigada. Pero henos aquí frente a un conjunto de procesos judiciales dirigidos contra los indígenas apóstatas en los que se puede ver que los diversos jueces a quienes les correspondió conocer de los autos aplicaron con mesura la pena más grave -cárcel- al delito más grave -idolatría-. La práctica judicial no se alejó de los planteamientos teóricos del jesuita Joseph Arriaga, de los arzobispos Bartolomé Lobo Guerrero o Pedro de Villagómez, quienes sostenían que en el amplio espectro de las idolatrías había que diferenciar si se trataba de hechiceros y dogmatizadores o de indios que por efecto del olvido y mala doctrina seguían mochando sus huacas y mallquis. Esta actitud, en definitiva, se impuso en los visitadores de idolatrías, quienes al tiempo de fallar hicieron la distinción correspondiente, lo que se reflejó en la proporcionalidad de las penas que aplicaron a los condenados.

Finalmente, en conjunto con la pena, el visitador de idolatrías imponía una penitencia al reo condenado, cuyo objetivo era que el idólatra se reconciliara y reinsertara en la comunidad cristiana. Con todo, debemos establecer que la penitencia no suprime el delito, puesto que el acto de confesar ante el juez lleva a la pena, mientras que confesarse ante Dios lleva al perdón o expiación. En buenas cuentas, las dos esferas jurídicas -Derecho sacro y Derecho profano- se mantienen diferenciadas.

${ }^{20}$ En tal sentido Tomás y VALIENTE, cit. (n. 2), p. 359, señala: "Una misma pena para el que comete hurto doméstico, por pequeño que sea, en Madrid, y para quien roba con violencia en despoblado; una misma pena para el padrino de un desafío entre nobles y para el monedero falso; una misma pena para el sodomita y para el que comete un delito de traición al rey; una misma pena para el bandido que tiene aterrorizada una comarca y para el hombre que tiene trato carnal con un animal. Y esa misma pena es siempre la muerte. Por eso, como un último intento de respetar la proporcionalidad y, al mismo tiempo, persiguiendo esa intimidación que tanto importa, se aplica la pena de muerte en diversas formas: la horca para los plebeyos, y no para los nobles; la muerte de saeta para los casos de Hermandad [...]”. 
El derecho canónico contenía entre sus normas una serie de penitencias espirituales, como la oración, la asistencia a una misa pública, el adoctrinamiento por un período de tiempo. Así, al reo se le podía condenar a las penas corporales más las penitencias espirituales, o bien sólo a estas últimas, cuando: "[...] por no temerse que seran perjudiciales a los otros, se les pondra por pena que acuda todos los días a la doctrina por la mañana y tarde y que no falten della sin licencia del cura [... $]^{21}$.

En la causa seguida contra Juan Chuchu, se concluyó que era culpable de haber sacado cadáveres de sus tumbas, penalizándolo de la manera que sigue: "[...] de condenar y condeno al dicho Juan Chuchu a que salga con Guasca y cruz en las manos y a que sirva un año en la yglesia de dicho pueblo y acuda a la doctrina con los muchachos" 22 .

Ahora bien, de los registros analizados podemos concluir que 543 personas fueron condenadas por las visitas de idolatrías. De ellas, 209 son mujeres; y 204, varones, desconociendo el sexo del $22 \%$ restante de los condenados.

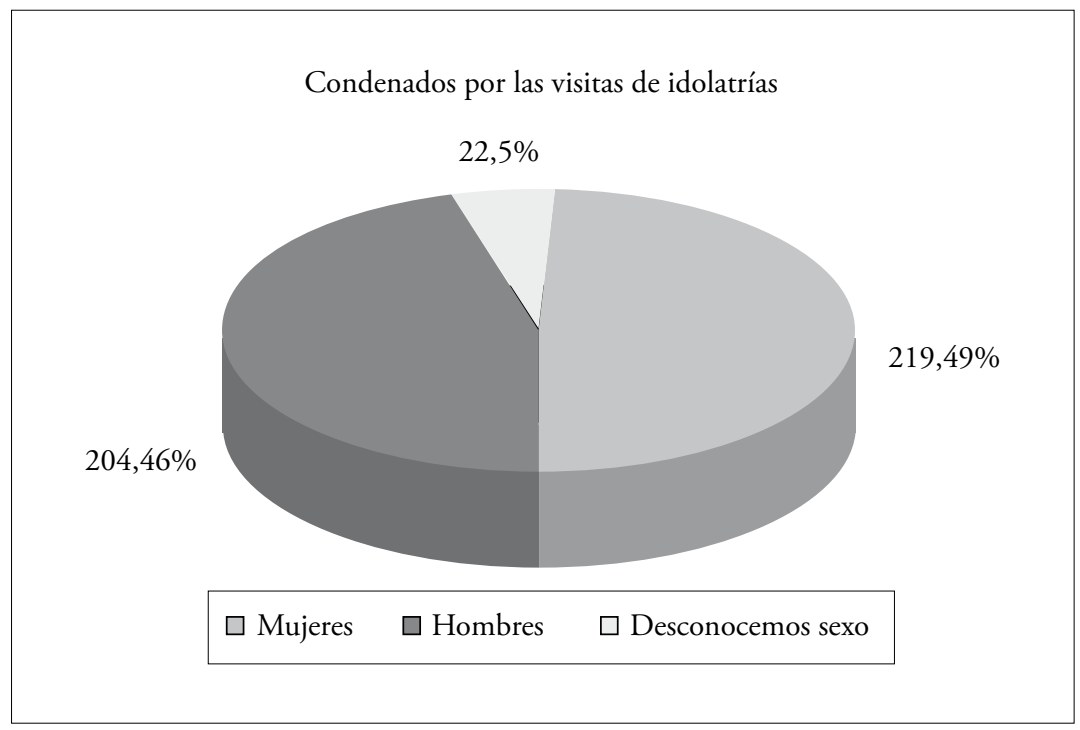

De los 543 condenados sólo conocemos las penas aplicadas al $58.9 \%$ de ellos, ignorando las penas dictaminadas al no despreciable número de 223 personas, equivalente al $41.06 \%$ del total.

\footnotetext{
${ }^{21}$ VillagómeZ, Pedro de, Carta Pastoral de exhortación e instrucción acerca de las idolatrías de los indios del arzobispado de Lima (Lima, 1649), p. 68.

${ }^{22}$ AAL, Leg. III, exp. 8: "Causa hecha contra los camachicos del pueblo de Santo Domingo de Pariac por auer sacado los cuerpos cristianos de la yglesia y llevandolos a los machayes y otras ydolatrias", 1656.
} 


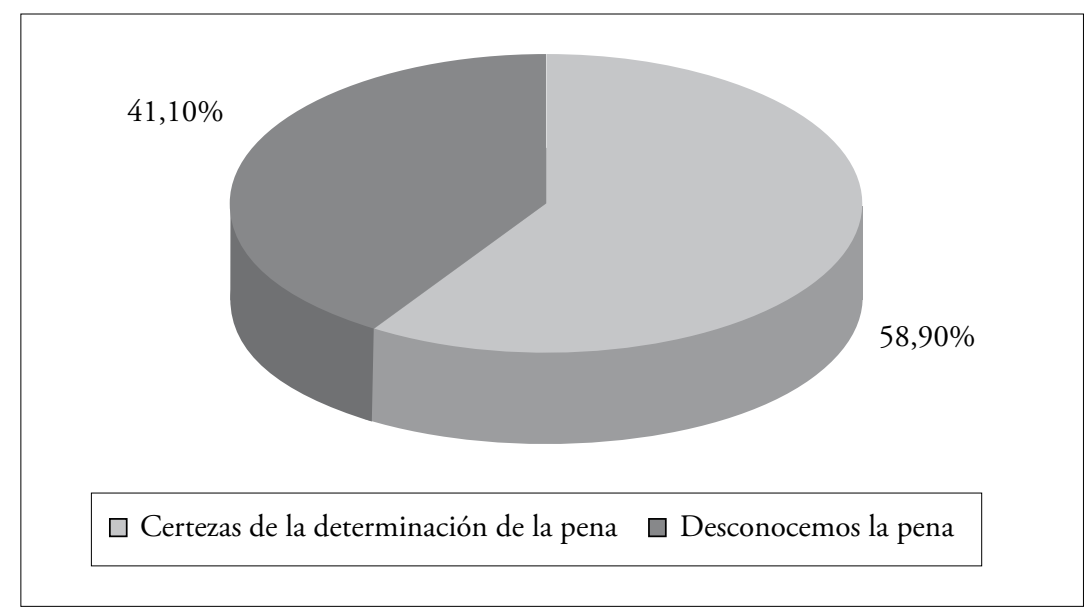

III. LAS PENAS DE TRASQUILACIÓN, AZOTES Y VERGÜENZA

La pena de azotes consistía en latigazos que se daban sobre la espalda desnuda del reo y su cantidad era determinada por el visitador de idolatrías. Esta pena tenía un fuerte contenido penitencial, además de la propiamente punitiva, puesto que: “[... está ligada a la búsqueda de la perfección espiritual de la Iglesia católica, pues no hay que olvidar que la administración por propia mano de las disciplinas o azotes ha sido una práctica, no solo permitida, sino en ocasiones, recomendada por las reglas de algunas órdenes religiosas ${ }^{23}$ ".

Asimismo, esta pena no sólo tuvo como objetivo el castigo corporal, además significaba para el condenado una ignominia o descrédito de su honor, toda vez que ella se aplicaba por las calles más concurridas del pueblo y con un pregonero que daba cuenta a los habitantes y vecinos del delito cometido por el reo ${ }^{24}$ : "[...] como consta destos autos [...] son culpados [...] en las idolatrías que an cometido los principales y demas yndios e yndias de este dicho pueblo en tan grande ofensa de Dios nuestro señor [...] que se executeen ellos la pena que mereçen en quanto puede y de derecho a lugar mandaba y mando sean sacados de la carçel y prision donde estan $y$ atadas las manos con boz de pregonero que manifieste sus delitos y pecados publicos le sean dado por las calles acostumbradas a cada uno çien açotes [...]"25.

En cuanto a la cantidad de azotes que se podía inferir a un reo, ello quedaba sujeto al arbitrio del visitador. Con todo, la Carta Pastoral de Villagómez señalaba al respecto algunas distinciones que se debían aplicar al momento de fallar: " $Y$ el indio particular no fuere cacique, alcalde, mayordomo, o mandon y que mandare

${ }^{23}$ García-Molina Riquelme, Antonio, El régimen de penas y penitencias en el Tribunal de la Inquisición de México (México, Universidad Nacional Autónoma de México, 1999), p. 435.

${ }^{24}$ En general esta pena fue aplicada por la Inquisición a delitos menos graves, pues no causaba perjuicios irreversibles. Este mismo criterio está recogido en Partida VII,31,4, y aplicado por las visitas de idolatrías.

${ }^{25}$ AAL, leg. I. exp. 2: "San Miguel de Cauri”, 1615. 
por la primera vez cincuenta azotes en el rollo con voz de pregonero que manifieste su delito, y por la segunda ciento, y por la tercera sea desterrado por tiempo de un año, abiendole dado cien azotes y quitadole el cabello y sobre el cumplimiento deste mandato se le encargara gravemente la conciencia al cura"26.

Junto con la ignominia y el descrédito del honor, la pena de azotes generalmente iba acompañada de la pena de vergüenza pública, castigo infamante que consistía en la exposición del condenado con una coroza en la cabeza, soga al cuello, cirio en la mano o montado sobre una llama o asno recorriendo las calles del pueblo. Así lo relata la Carta Annua de 1660-1662 al decir: "[...] hizo sacar por la plasa veytidos de estos ydolatras y hechiceros con corozas en la cabeza, Cruces en los pechos atadas al cuello las brujerías e instrumentos de su deprabado ministerio $y$ descubiertas las espaldas a voz de pregonero, que manifestaua el delito merecedor de aquel castigo le hacia dar en ellas conpetente cantidad de acotes para escarmiento de los demás" 27 .

Constituía en sí un espectáculo, pues todos notaban visualmente la aplicación de la pena. Un ejemplo de ello fue el caso de Hernando Julca, a quien: "[...] mandaba y mando [...] que quando este toda la gente del dicho pueblo junta y congregada sea sacado el dicho Hernando Julca desnudo de la çentura arriva en una bestia de enjalma y se le den cien azotes por las calles publicas deste dicho pueblo [...]"28.

Así pues, variantes de la vergüenza pública fueron la soga al cuello, pena aplicada por la Inquisición y trasladada a las visitas de idolatrías, que consistía en una cuerda con nudos que se amarraba al cuello ${ }^{29}$. También podía establecerse la coroza en la cabeza, consistente en un cucurucho que se ponía en la cabeza por castigo, en el que había generalmente un dibujo alusivo a la afrenta cometida por el reo. Y la vela o cirio prendido ${ }^{30}$, que era un símbolo de fe que sólo se encendía luego de la abjuración del reo ${ }^{31}$.

Sumado a lo anterior, las visitas de idolatrías castigaron a los indios con la pena de trasquilación, variante indiana de la vergüenza, que consistió en rapar la cabeza, corte de cejas y pasear ante los ojos de los habitantes al nativo idólatra, sin distinción de sexo o edad, la que fue considerada por los indígenas como grave y severa. Lo anterior, porque un signo de estatus al interior de las comunidades

${ }^{26}$ Villagómez, Pedro de, cit. (n. 21), f. 72 y vuelta.

${ }^{27}$ ARSI Perú 16: "Carta Annua”, 1660-1662.

${ }^{28}$ AAL, leg. II, exp. 1: "Aberiguacion y auto contra Hernando Julca, yndio, por hechicero".

${ }^{29}$ Respecto a la pena de soga al cuello, no existe disposición que la regule y establezca su significado. Con todo, es una pena introducida por la Inquisición, que ha sido objeto de discusión en lo relativo al significado de sus nudos. Véase: LEA, Henry, cit. (n. 8),II. p. 649. Maqueda Abreu, Consuelo, El auto de fe, en Escudero, José Antonio (editor), cit. (n. 6), p. 238.

${ }^{30}$ Partida I,6,11.

${ }^{31}$ La Inquisición Española aplicó otras variantes de vergüenza pública como el sambenito, la mordaza, la asistencia a misa en forma de penitente, portar algún elemento alusivo al delito, el cuerpo sin cinto ni bonete, entre otras. Para más detalles véase: EIMERIC, Nicolau, El manual de los inquisidores (Barcelona, Muchnik Editores, 1983); LEA, Henry, cit. (n. 7); García-Molina Riquelme, Antonio, cit. (n. 23). 
era el cabello: "el trasquilallos sienten mucho, porque tienen por grande ornato la coleta del cabello [...]"32.

La trasquilación dejaba al reo en evidencia de haber cometido un delito, y de paso, humillado frente a sus pares por haber perdido su honor producto de su actuar: "[...] el señor visitador dezia las que las tubieran avian de ser castigadas una vezina mia las tenia yo y luego al ynstante por las calles me dieron con pregon çien azotes y mas me trasquilaron como bruja y hechicera [...]"33.

Asimismo, penas como portar la cruz al cuello a perpetuidad o por un cierto período ${ }^{34}$ fueron castigos que conllevaron una humillación pública, toda vez que, mediante ese tipo de signos externos, el pueblo tenía conciencia de la calidad de delincuente del indígena. Además, mediante la cruz se perpetuaba el delito y castigo por todo el tiempo que le correspondía portarla al culpable.

En otras palabras, las penas de azotes, trasquilación o de portar la cruz implicaban una deshonra. Junto con esto, el carácter público de las penas, al imponerlas en las plazas o calles del pueblo, en presencia de todos los habitantes, importaba una degradación y menoscabo del indígena, quien quedaba frente a sus pares reducido y castigado por contrariar normas y principios cristianos.

Así pues, a través de este tipo de sanciones se producía un impacto psicológico en todos los habitantes, fuesen o no sinceramente cristianos, puesto que mediante la pérdida del honor y la humillación infligida por estas penas, se buscaba socavar la pervivencia de la idolatría colonial y enrielar a quienes estuviesen confundidos en asuntos de fe. Es por ello que estas penas fueron las que mejor contribuyeron a alcanzar la finalidad ejemplificadora que tenía el derecho penal del Antiguo Régimen, pues se llevaban a cabo en los espacios públicos, en presencia de todos.

Conforme consignan los expedientes de idolatrías, las penas más frecuentemente aplicadas fueron la confiscación de bienes, la obligación de portar la cruz al cuello, la de azotes y la de pasear al culpable en burro u otro animal con coroza mientras el pregonero comunicaba al pueblo el delito atribuido al condenado. Esto sin embargo, no considera la información proporcionada por los visitadores de idolatrías a los arzobispos ni la consignada en la correspondencia de los jesuitas.

${ }^{32}$ Arriaga, Pablo de, Extirpación de la Idolatría en el Perú (Cuzco, Centro de Estudios Regionales Andinos Bartolomé de las Casas, 1999), p. 126. En sentido similar BETANZOS, Juan de, Suma y narración de los Incas. (Madrid, Atlas, 1987), p. 30, señala que el Inca Yupanqui al vencer a los chancas mandó "por cuanto eran orejones, que luego les fueran trasquilados sus cabellos". La incorporación de la pena de trasquilación se puede interpretar como una transculturación colonial, en el sentido que se trata de una infamia que los indígenas aplicaban, siendo adaptada por los españoles para aplicarla en quienes precisamente importaba una ofensa y vergüenza.

${ }^{33} \mathrm{AAL}$, leg. V, exp. 3.

${ }^{34}$ Villagómez, Pedro de, cit. (n. 21), p. 68. 
Penas comúnmente imputadas

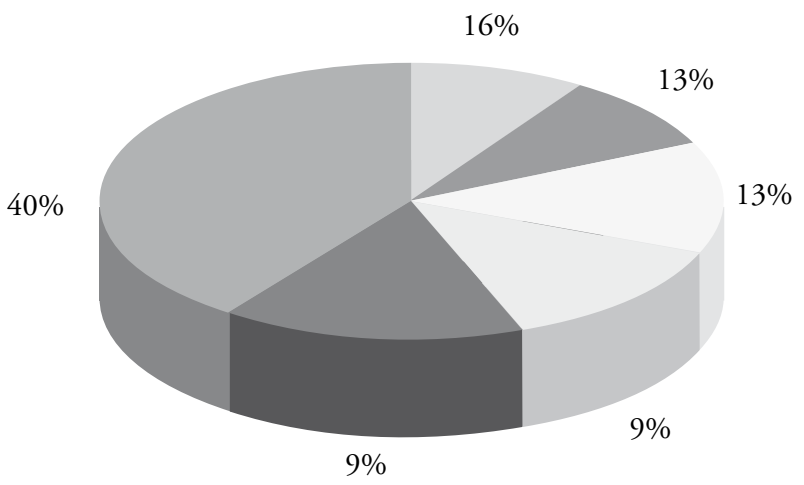
$\square$ Portar la cruz al cuello
$\square$ Azote
$\square$ Pasear sobre un animal por todo el pueblo
$\square$ Confiscación de bienes
$\square$ Otra

En efecto, el 16\% de los fallos estableció la obligación de portar la cruz al cuello por un tiempo que iba de los 6 meses a la perpetuidad, según el delito y criterio del visitador de idolatría. Esta condena fue aplicada tanto a mujeres como varones en una proporción de 69,2\% y $30.75 \%$, respectivamente.

Condenados a la pena de portar la cruz al cuello de acuerdo al sexo

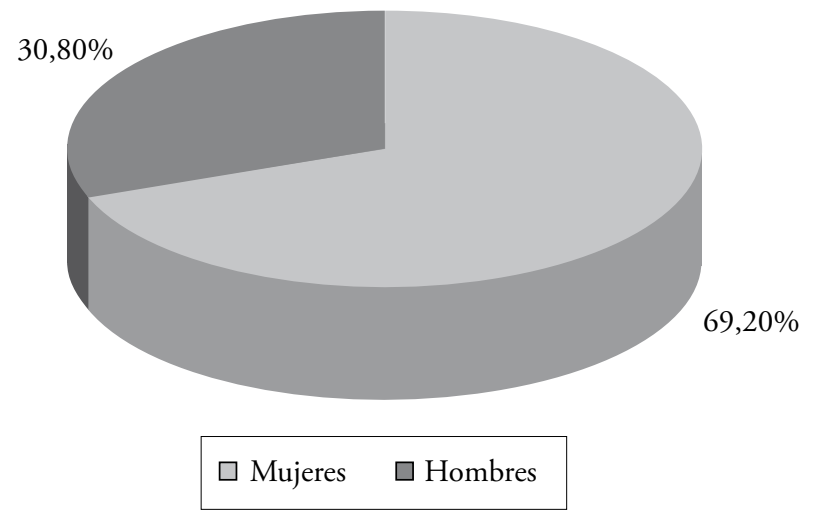


Seguidamente, el 13\% de los condenados fue sentenciado a la pena de azotes, cuya cantidad variaba conforme a la gravedad del delito, el criterio del visitador, el sexo y la edad del culpable, entre otras variables.

Según lo constatado, del 13\% referido el $63.4 \%$ fueron mujeres. Sin embargo, en algunas oportunidades, ellas vieron atenuada la pena mediante una disminución de la cantidad de azotes (siempre inferior al sufrido por los varones) o en la conmuta de la sanción por otros castigos.

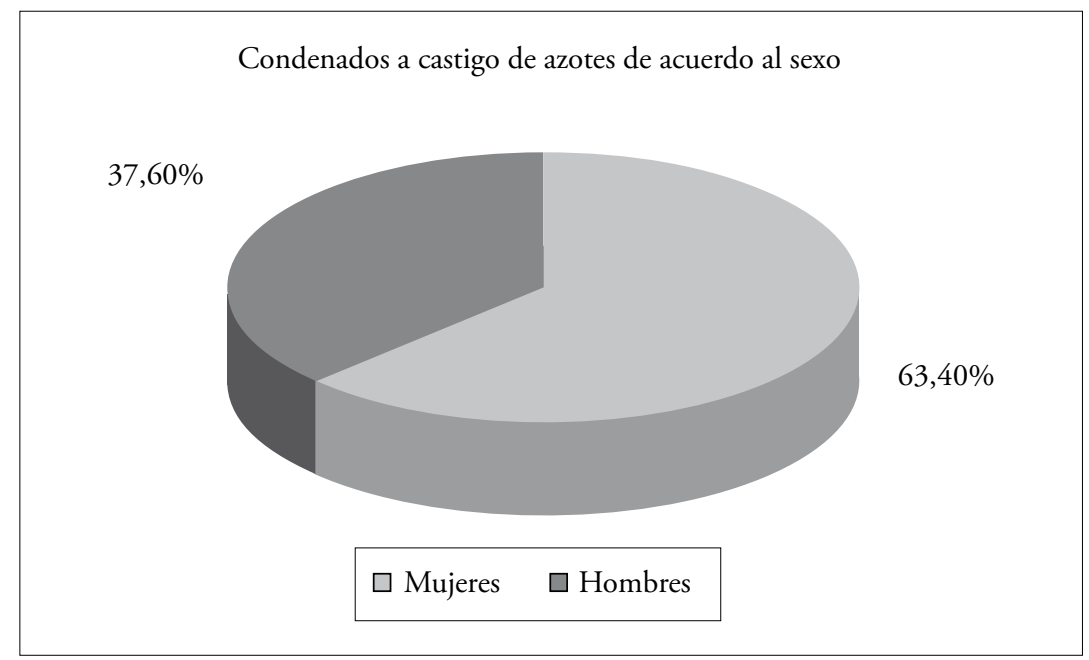

Un $9 \%$ de los sentenciados debió portar la coroza. De ese total, el $68.9 \%$ fueron mujeres.

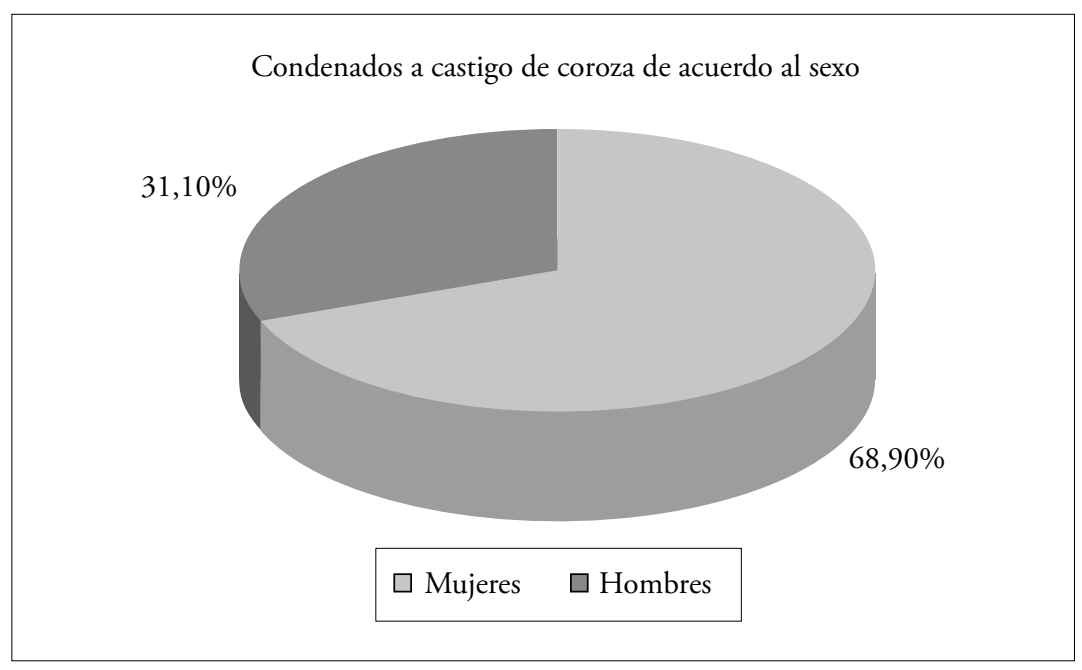




\section{Penas de CARÁ́cter eConómico}

De acuerdo con el sistema correccional y penitenciario del Antiguo Régimen se estableció la equivalencia entre el daño producido, en nuestro caso por una idolatría, y el castigo consistente en la privación de bienes del idólatra. Tales penas económicas podían ser de dos tipos. A saber: la pena pecuniaria, que eran multas en dinero que el visitador de idolatrías imponía al reo, las que eran destinadas a la Iglesia como satisfacción por los pecados cometidos ${ }^{35}$. Así pues, en la causa seguida contra María de la Cruz y otras mujeres, por el delito de proveer brebajes y otras pócimas, para asuntos de amor y hechicerías, el visitador de idolatrías Juan de Sarmiento de Vivero resolvió aplicar como pena multas en dinero: "Ya a la dicha Maria de la Cruz, doña Josepha de Escobar y Anna de Ozerin las condenava a cada una por via de multa y condenación en diez pesos de a ocho reales por mitad conforme al nuevo orden dado por su Majestad y en las costas de esta causa, sin que se tripliquen conforme la ley real sino que cada qual pague lo que pareciere aver echo de costas en sus declaraçiones denunciaciones y confesiones [...]"36.

Por otra parte, las penas económicas también podían consistir en la confiscación de los bienes del condenado, debiéndose tener en cuenta para su cuantificación: la calidad del reo en orden a su riqueza, y la gravedad del delito. Ahora bien, al igual que la Inquisición y la Justicia Penal ${ }^{37}$, los visitadores la impusieron a las acciones de idolatrías más graves, pues implicaba la pérdida de todos los bienes $^{38}$ y la ruina familiar.

Para aplicar la pena de la confiscación de bienes, se procedía primeramente a embargarlos para luego rematarlos a beneficio de la Corona: "[...] dixo que en la dicha vesita a resultado que los dichos ministros de ydolos tenian casa y en ella ocho pesos en moclones de las ofrendas que avian hecho a los dichos idolos y vna fanega $y$ vn selmin de mais para el seruisio de sus dichos ydolos los quales bienes pertenecen a su magestady son confiscados por derecho y para que se puedan bender por aueres del rei nuestro señor [...] y como tal los confisco y mando que el dicho mais se mida y venda y los ochos pesos de moclones en publica almoneda a quien diere mas por tal

${ }^{35}$ La pena pecuniaria tiene un origen en la Edad Media, siendo readaptada por la Inquisición Española. Para más detalles, véase: García-Molina Riquelme, Antonio, cit. (n. 23), pp. 391 ss. Como se ha señalado, las penas pecuniarias, fuesen multas o confiscaciones, fueron utilizadas por la justicia penal del Antiguo Régimen, cumpliendo al igual que en las visitas de idolatrías la finalidad de equilibrar el daño causado por el delincuente a la víctima directa del hecho, como en el estupro, donde el victimario debía de pagar una suma de dinero a la doncella víctima del delito. Tomás y Valiente, cit. (n. 2), pp. 361 y 393. Del mismo modo, el idólatra debía compensar a la Iglesia, víctima del delito de idolatría.

${ }^{36}$ AAL, leg. VI, exp. 8

${ }^{37}$ La pena de confiscación era utilizada por la Inquisición cuando el reo era culpable de herejía. Por su parte la justicia penal la aplicaba en delitos graves como la traición, falsificación de moneda, formas agravadas de homicidio, acompañada de la pena de muerte. Respecto de la justicia o injusticia de la pena, poco es lo que dicen los penalistas de la época. TOMÁs Y VAliente, cit. (n. 2), p. 393.

${ }^{38}$ Con todo, las visitas de idolatrías no impusieron esta pena a idólatras fallecidos, a diferencia de lo que aconteció en el Santo Oficio. 
remate y de los procedido se pague al notario desta uisita el trabajo de lo escrito de los autos y visita y a Miguel Sanches y a Juan cristiual de Mendosa su trabajo de oficio de interpretes y otorguen carta de pago [...]"39.

Ahora bien, los bienes embargados para su posterior remate consistieron generalmente en ganado, maíz u otro tipo de productos agrícolas. Podía suceder que los ídolos hallados fuesen de oro, plata o tuviesen algún valor, y por lo tanto eran confiscados a beneficio de la Corona: "[...] aquillas y vasos, trompetas y huamas y las demás cosas que se hallan de plata, aunque sean de poco valor se pesan y toman por cuenta en estas exhibiciones públicamente y se escribe en el proceso para dar quenta de ello a quien se debe dar y asi estas exhibiciones las firman el visitador y los padres que se hallan presentes porque importa más de lo que se puede fácilmente entender que los indios vean y se persuaden que no se pretenden en estas visitas quitarles cosa ninguna suya sino solo aquello que sin ser de provecho para nadie, es el perjuicio de todos y ofensa de Dios nuestro Señor [...]"40.

Un total de 9\% de los condenados sufrió esta pena. El 67.8\% fue aplicado a varones, implicando con ello una severa merma de sus patrimonios.

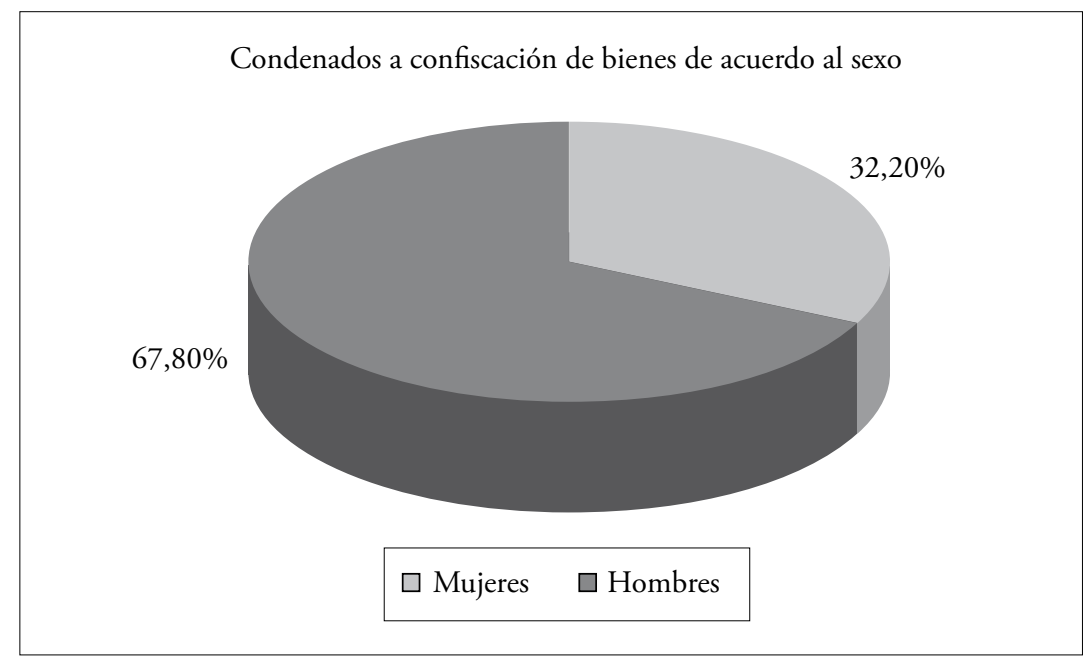

\section{Pena de destierro}

Esta pena restringía la libertad de circulación del condenado pues le impedía por un cierto tiempo el ingreso a los lugares o ciudades señalados en la sentencia, constituyendo la prueba más concreta de la eliminación espacial de los sujetos indeseados ${ }^{41}$. Asimismo, implicaba generalmente, un perjuicio económico y social

${ }^{39}$ AAL, leg. V, exp. 1: "Causa de ydolatrias contra los yndios hechiceros de los aillos de Chamas y Nanis deste pueblo de señor San Francisco de Mangas”, 1663.

${ }^{40}$ Arriaga, Pablo de, cit. (n. 32), p. 138 s.

${ }^{41}$ En el mismo sentido: AraYA, Alejandra, Ociosos, vagabundos y malentretenidos (Santiago, 
pues el sentenciado quedaba alejado de su familia, amigos y privado de la fuente de obtención de sus recursos ${ }^{42}$.

La pena de destierro impuesta por las visitas de idolatrías consistió en prohibir a los reos estar físicamente en un determinado lugar, que generalmente correspondía al pueblo donde eran conocidos por sus idolatrías. De esta forma la pena cumplía un doble objetivo. Por una parte, aislaba y alejaba al delincuente del lugar de la comisión del delito, y, por la otra, tenía una finalidad ejemplificadora, en el sentido de que el pueblo escarmentaba al comprobar que el reo era arrancado de su casa y se le prohibía volver.

No obstante, la pena de destierro impuesta al culpable de idolatría no sólo se podía circunscribir a un pueblo o ciudad determinada; era completamente posible que el juez la ampliara a grandes extensiones, o incluso a todo el territorio del arzobispado, como sucedió con Joana Muñoz, vendedora de coca, a quien se condenó al destierro por cuatro años de la diócesis de Lima ${ }^{43}$.

En cuanto a su duración, era relativa, pues podía ir de meses a años, siendo la generalidad de ellas de dos años. Con todo, si el reo rompía la pena, el tribunal mediante la "cláusula de quebrantamiento "44" podía duplicar el período de destierro: "[...] Ana Maria de Ribera [...] y en rason de ser vendedora de coca [...] con pena de sien asotes y dos años de destierro treinta leguas del contorno de esta ciudad $[\ldots] "$...5.

\section{Pena de Galeras}

La pena de galeras consistía en la entrega del condenado por el visitador de idolatrías a las autoridades civiles para su traslado y posterior embarque en una nave, tipo galera, donde el sentenciado debía remar para propulsar el navío.

La pena de galeras no fue conocida durante el medioevo, sino que fue utilizada en España por la Inquisición, probablemente por un asunto económico, puesto que favorecía al Tribunal y a la Corona al evitarse tener que mantener en las cárceles perpetuas a los condenados, prestándose de paso un servicio ${ }^{46}$ y excluyendo del pueblo al peligroso e indeseado hereje.

En Lima durante el siglo XVII fue utilizada por la Inquisición Española. De ahí pasó a las visitas de idolatrías, en las que se conservaron ciertos requisitos establecidos por la Inquisición. Esto es, aplicarla sólo a hombres, atendiendo al estado de salud y edad del sancionado.

Ahora bien, la pena de galeras era extremadamente dura, pues implicaba des-

DIBAM, Centro de Investigaciones Barros Arana, Lom, 1999), p. 64.

${ }^{42}$ La pena de destierro se encuentra contemplada en Partidas VI,3,4.

${ }^{43}$ AAL, leg. VI, exp. 15.

${ }^{44}$ Cláusula de quebrantamiento consiste en una advertencia que se le hacía al reo en caso de que volviera sin autorización antes del tiempo de la condena. Para más detalles, véase: : Las Partidas. 7,31,10. Tomás y Valiente, cit. (n. 2), p. 392.

${ }^{45}$ AAL, leg. VI. exp. 14.

${ }^{46}$ Fernández Giménez, María del Camino, La sentencia inquisitorial (Madrid, Editorial Complutense, 2000), p. 179; García-Molina, Antonio, cit. (n. 23), p. 214; Tomás y Valiente, cit. (n. 2), p. 357; LEA, Henry, cit. (n. 8), II, p. 653. 
gastes serios en la salud del reo, incluso su muerte. Es por ello que en las visitas de idolatrías, esta pena se impuso, casi siempre, a los reos relapsos. A su vez, en caso que el sentenciado por idolatría no cumpliese la pena dada por el visitador, generalmente la cláusula de quebrantamiento establecía la pena de galeras. Pero en definitiva, la aplicación efectiva de la pena de galeras fue muy escasa, precisamente por las consecuencias que presentaba. De ahí que en muchas causas la pena es impuesta, pero conmutada por otras.

\section{Cárcel de Santa Cruz}

La pena de cárcel, tal como la entendemos en la actualidad, fue implementada por el sistema penal moderno, a diferencia de lo que ocurría en el Antiguo Régimen, donde sólo tenía un carácter preventivo ${ }^{47}$, orientado a asegurar la comparecencia del delincuente en el juicio ${ }^{48}$.

Ahora bien, para el Derecho canónico la pena de cárcel era de las más graves, pues equivalía a la de muerte, pena que la Iglesia no podía aplicar. Con todo, el Derecho canónico contempló en su ordenamiento la pena de reclusión en un monasterio para los clérigos autores de algún delito, cuyo objetivo era que el delincuente se arrepintiese luego de haber meditado en una celda aislada. Por lo que la cárcel tuvo más un carácter de penitencia que de pena ${ }^{49}$.

La Inquisición, por su parte, incorporó la cárcel para castigar a los herejes penitentes, con la particularidad de que los condenados a ella pasaban todo el día en la calle y durante la noche volvían para recluirse. Estas eran las llamadas cárceles de penitencia.

A su vez, la Inquisición estableció una modalidad de la cárcel de penitencia, conocida con el nombre de reclusión, cuyo objetivo fue que el delincuente por delitos leves o menores estuviese confinado en un monasterio u hospital por un período realizando trabajos de asistencia a enfermos o pobres menores.

La pena de cárcel impuesta por las visitas de idolatrías consistió en privar de libertad al delincuente con la finalidad de que el idólatra escarmentara, se desengañara de su falsa creencia, se arrepintiera de su error y volviese al seno de la Iglesia. Pero además se pretendía que, mediante su encierro, el reo no continuara delinquiendo, por constituir un peligro para la comunidad, de tal manera que este castigo tenía la doble calidad de pena y penitencia. Pena porque mediante

${ }^{47}$ Tomás y Valiente, cit. (n. 2), p. 387, establece que la pena de cárcel solo tenía carácter preventivo, puesto que se basaba en el derecho romano, que consideraba la prisión perpetua equivalente a la esclavitud, la que no se podía aplicar a los hombres libres. Por su parte LEÓN, Marco Antonio, cit. (n. 11), p. 58, afirma: "Respecto de la prisión, es preciso indicar que ésta ocupaba un lugar marginal dentro del inventario de penas establecidos por las monarquías europeas, ya que la privación de libertad no era considerada en sí misma como un castigo [...] su misión estaba más bien restringida a ser un espacio de encierro preventivo, donde el inculpado esperaba la sentencia por su delito".

${ }^{48}$ Partida VII,31,4: “[...] Ca la carcel non es dada para escarmentar los yerros: mas para guardar los presos tan solamente en ella, fasta que sean judgados [...]”.

${ }^{49}$ Donoso, Justo, Instituciones del Derecho canónico americano (Paris, Librería de Rosa y Bouret, 1858), III, p. 327. 
el encierro del delincuente se lograba apartarlo de la sociedad y prevenir nuevos delitos. Y penitencia porque se procuraba su arrepentimiento. Asimismo, tuvo una finalidad utilitarista, puesto que los presos estaban obligados a realizar trabajos para su manutención.

En buenas cuentas, la pena de cárcel impuesta por los visitadores de idolatría se acerca en algunos aspectos al moderno concepto de cárcel, puesto que el objetivo fundamental que persiguió la legislación antiidolátrica con esta pena fue impedir que el delincuente siguiera delinquiendo, y, al mismo tiempo, evitar exponer a la comunidad a actos que la pudiesen afectar. De ahí que la pena de cárcel tuvo un carácter excepcionalísimo, ya que se aplicó sólo a aquellos que con su actuar pudiesen poner en jaque la religión católica: “[...] que muchas veces se ha ordenado se traigan a la Casa de Santa Cruz del Cercado todos los indios ministros de idolatría que se han huido de ella y los demás que en sus pueblos han sido relapsos, o son muy perjudiciales $[\ldots] "$...

Es más, el virrey Príncipe de Esquilache fue enfático al informar a la Corona que: "Ordeneles a los visitadores que prendiesen a todos los dogmatizadores de los indios y que los remitiesen a una reclusión que fabrico en el Cercado, donde estarán ocupados y enseñados, sin comunicación de otros indios porque con esto se atajará la contagión que con su mala doctrina a cundido entre tantos" 51.

Así pues, la cárcel de Santa Cruz se creó sólo para aquellos indígenas que fuesen hechiceros, dogmatizadores o confesores, que tenían influjo en sus comunidades, y que como tales podían instigar a que los indios volviesen a las idolatrías.

Una vez que se determinó quiénes iban a ser recluidos en la cárcel especial para indios, el arzobispo Lobo Guerrero consideró necesario que el establecimiento fuese construido en un lugar que impidiese que los sacerdotes paganos "les enseñen sus falsos ritos y aconsejen que perseveren en ellos y desdeñen la Religión Cristiana [...]”.

Para cumplir los fines propuestos, la cárcel se estableció en Lima. De esa manera se cumplía el objetivo de mantener aislados e imposibilitados de influir en las comunidades a los hechiceros, dogmatizadores y sacerdotes. Asimismo, se proyectó que al interior de esta cárcel los nativos serían fuertemente adoctrinados en la religión católica, debiendo, además, prestar servicios a la comunidad como compensación por los males que habían realizado al desconocer la fe católica, así como también para ganarse el pan de cada día ${ }^{52}$.

Seguidamente, como el sistema de las visitas de idolatrías formaba parte del plan de asentar la religión católica en las comunidades periféricas de la diócesis

\footnotetext{
50 "Ordenanza que crea la Casa de Santa Cruz", en Revista Inca, 1 (1923) 4, p. 76.

51 "Carta del Príncipe de Esquilache al Rey", Lima, 15 de abril de 1617, en Mss. "Colección Vargas”, en Vargas Ugarte, Rubén, Historia eclesiástica del Perú (Burgos, 1959), II, p. 312.

52 "En la casa de Santa Cruz, que sirve de reclusión para los más perjudiciales maestros y ministros de idolatrías [...] no salen sino en los días de fiesta a misa y sermón en procesión con sus fiscales; aquí se les enseña cada día uno de nuestros Padres la doctrina. Dáseles por orden del virrey suficientemente de comer, porque aunque tienen muchos tornos armados para hilar lana, que es oficio fácil y muy usado por los indios para que ganen su comida [...]”: Arriaga, Pablo de, cit. (n. 32), p. 148.
} 
de Lima, la reclusión en la cárcel debía provocar: "[...] que la conversión destos sea verdadera y que no vuelan a sus idolatrías y ritos en que el demonio los tiene tan ciegos $[\ldots] "$... 33 .

Ahora bien, para dar curso a la creación de una cárcel especial para indios hechiceros y dogmatizadores, Lobo Guerrero solicitó la ayuda de la Corona, no sólo para financiar su construcción, sino que también para contar con la plena autoridad para realizar el proyecto y evitar así posibles críticas o protestas de sectores contrarios a la medida ${ }^{54}$. La Corona acogió la petición y ordenó al virrey Príncipe de Esquilache que colaborara con el arzobispo. Y así lo hizo. Al poco tiempo, Esquilache dispuso la fundación de una casa de reclusión anexa al pueblo del Cercado, cuyos planos y construcción fueron encargados al padre Pablo de Arriaga $^{55}$.

Incluso más, comprometido con el sistema forjado por Lobo Guerrero, Esquilache se encargó de notificar a los visitadores de idolatrías de la construcción de esta nueva cárcel para dogmatizadores, explicándoles sus fines y objetivos: "Ordeneles a los visitadores que prendiesen a todos los dogmatizadores de los indios y que los remitiesen a una reclusión que fabrico en el Cercado, donde estarán ocupados y enseñados, sin comunicación de otros indios porque con esto se atajará la contagión que con su mala doctrina a cundido entre tantos" 56 .

La Cárcel de Santa Cruz quedó regentada por la Compañía de Jesús, cuyos sacerdotes tuvieron que velar por la conversión y adoctrinamiento de estos indígenas. Para ello vital fue establecer un régimen de trabajo, que consistió en hilar lana bajo la dirección de un intendente español. Mediante ese trabajo los indios pagaban su comida durante su reclusión ${ }^{57}$.

El tiempo de estadía en esta cárcel era generalmente de por vida -y en este aspecto, preanuncia el concepto moderno de prisión-, puesto que se estaba en presencia del mayor mal y peligro al que podía quedar expuesta la religión católica en los Andes. Por ende, se hacía imperioso contrarrestar el peso que tenían estos idólatras en sus pueblos. Más aún, la Iglesia desde hacía mucho había comprendido que el actuar de los falsos sacerdotes socavaba el esfuerzo evangelizador de las diversas órdenes religiosas. Como señalaba un sacerdote al jesuita Arriaga, bastaba con nombrar la Casa de Santa Cruz, y lo que ello implicaba, para que los indios, temerosos y asustados, iniciaran sus confesiones y adoctrinamiento ${ }^{58}$.

Con todo, y pese a que estamos en presencia de la pena más severa y dura que aplicaban los visitadores de idolatrías, no es menos cierto que el encierro de por

${ }^{53}$ AGI, Lima, 301: “Carta del arzobispo Lobo Guerreo al Rey”, 20 de abril de 1611.

${ }^{54}$ Ibíd.

${ }^{55}$ AGI, Lima, 301: "Carta del arzobispo Lobo Guerrero al Rey”, 9 de marzo de 1617. Para más detalles, véase: Duviols, Pierre, La lutte contre les religions autochtones dans le Pérou colonial (Paris, Institut Français d'Etudes Andines, 1971).

56 "Carta del Príncipe de Esquilache al Rey”, Lima, 15 de abril de 1617, en Mss. "Colección Vargas”, en: VArgas UGarte, cit. (n. 51), II, p. 312.

${ }^{57}$ Arriaga, Pablo de, cit. (n. 32), p. 148.

${ }^{58}$ Ibíd., p. 106. 
vida podía terminar cuando los culpables acreditaran que se habían corregido y convertido verdaderamente a la religión católica ${ }^{59}$.

Ahora bien, los extirpadores de idolatrías que visitaban las distintas doctrinas daban cumplimiento a lo ordenado por el arzobispo, e intentaban descubrir, detener y enviar a la Cárcel de Santa Cruz a todos los indios dogmatizadores y hechiceros, con el objetivo de mermar su influencia en las comunidades indígenas, tal como relata la Carta Annua de 1660-1662: "Entre estos fue más señalada una india hechisera que tenia vna piedra blanca y publicaua de ella tal virtud, que decia bastaua el agua donde vbiera entrado, para quitar todos los pecados del que se vañasse en tal agua, y que asi no era menester confessarse. Quien duda que con esta mentira y embuste tan pernicioso lleuaria tras de si a muchos que tanto rehusan acudir a este sacramento esta mala india por ser de tanto daño junto con otros siete de mas de nombre se mandaron lleuar a Lima ala cassa de s. ta Cruz que esta en el sercado edificada para este efecto de recluir semejante fente que nunbuelba a sus pueblos"60.

A su vez, mediante el encarcelamiento se pretendía lograr la conversión a la fe católica de los dogmatizadores y hechiceros. Por ello, la Compañía de Jesús, desde 1621, tuvo a su cargo la cárcel: "[...] En la casa de los hechiceros hay más de ciento cuarenta, a los cuales todos los dias se les hace doctrina y exhorta a que se manifiesten, con que se ha hecho mucho fruto confesando algunos pecados enormes"61.

En efecto, el padre Pablo de Arriaga señalaba que muchos de estos indios recluidos en la Casa de Santa Cruz, tocados de Dios, comenzaban a manifestar la existencia de las huacas habidas en sus pueblos. Es más: “[...] otro indio de éstos viejos viendose enfermo y desahuciado, sin esperanza de vida, llamó a un padre de los nuestros y le dijo que tomase por escrito todo lo que habia dejado encubierto, que pertenecía a sus huacas, porque quería morir como buen cristiano" 62.

Los resultados obtenidos en la Casa de Santa Cruz fueron mejores de lo que esperaban. Lobo Guerrero informó del éxito de la creación de la cárcel y de las esperanzas cifradas en ella y de la labor de la Compañía de Jesús para desarraigar el mal idolátrico extendido en las zonas rurales: "Vanse trayendo a la carcel que se ha hecho los dogmatistas, maestros y sacerdotes de la idolatría más perjudiciales, a donde estan como en la carcel perpetua porque no dañen a los demás y alli son instruidos y catequizados por los Padres de la Compañia que cierto Señor son los que les doctrinan con amor y solo por Dios y su bien espiritual; y al servicio que en ello se hace a V.M El Principe de Esquilache a acudido muy bien en todo aquello que ha sido a su cargo y a cabar la dicha carcel [...]"63.

La Casa de Santa Cruz funcionó como tal durante la primera oleada de visitas de idolatrías y también bajo el período del arzobispo Pedro de Villagómez. Así

59 "Los que vienen aquí por tiempo limitado salen cuando se cumple; los demás cuando se entienden que están escarmentados, enmendados y enseñados": ArriagA, Pablo de, cit. (n. 32), p. 149.

${ }^{60}$ ARSI, Perú 16: "Carta Annua”, 1660-1662.

61 “Carta Annua de la Provincia del Perú de la Compañía de Jesús”, 1621, en Revista de Archivos y Museos Nacionales, 5 (Lima, 1900, año III), p. 58.

${ }^{62}$ Arriaga, Pablo de, cit. (n. 32), p. 149.

${ }^{63}$ AGI, Lima, 301: "Carta del arzobispo Lobo Guerrero al Rey", 15 de abril de 1619. 
pues, vemos en 1662 al visitador de idolatrías Bernardo de Noboa condenar a un grupo de dogmatizadores y hechiceros a la mentada cárcel: " $Y$ a Domingo nunca callan en su ausencia y reveldia por docmatisador y ministro de los ydolos del dicho curaca y que repartia ydolos en el pueblo de Copa ya todos los repaxes de casas taria el dicho ydolo Coyahuarmi para que le isieran ofrendas y mochas en el dicho ydolo le dava respuestas al demonio le condeno en perpetuo destierro de su pueblo y que sea recluso en la Casa de Santa Crus del sercado y que se le den dusientos asotes y se le quite el cavello a bos de pregonero que manifieste su delito y por la misma causa a Pedro rimaichaua ministro de dichos ydolos le condeno a dusientos asotes y que sea trasquilado y desterrado por toda su vida de su pueblo y recluso en la casa de Santa Crus del Sercado" 64 .

Por lo demás, la Carta Pastoral del arzobispo Pedro de Villagómez señalaba expresamente: "Los hechizeros confesores y adivinos y demás ministros del demonio que tiene de oficio pervertir a los demás indios y apartarlos de la religión christiana, se pongan y encierren en un lugar apartado de los demás [...] a los que an sido perjudiciales para los demas sin remedio, los manden tener encerrados, pero no se les deje enseñar la doctrina y proveer de lo necesario con particular cuydado, para que sean salvos, mas si cuallquiera de los dichos hallare el cura, que es relapso, y como tal exercita las idolatrías y dogmatiza contra la fe, luego sin dilacion lo haga encarcelar y preso lo envie al diocesano para que lo castige con el rigor del derecho" ${ }^{35}$.

Finalmente cabe señalar que el tema de los hechiceros y dogmatizadores debió quitar el sueño a los organizadores de las visitas de idolatrías. Sabemos que el peligro más grande que podía enfrentar la Iglesia en las Indias era precisamente la existencia de estos dogmatizadores y sacerdotes de la idolatría. Es probable que su número haya sido elevado precisamente por las informaciones proporcionadas por los jesuitas Arriaga y Barraza ${ }^{66}$, pese a que de acuerdo a los fallos encontrados solo el $4 \%$ de los penalizados por idolatrías fueron castigados con la cárcel perpetua. El bajo porcentaje se explica a base de que se trataba de la pena más grave que se podía aplicar a un culpable. Por otra parte, debemos establecer desde ya, que esta pena se aplicó indistintamente a varones y mujeres, constituyendo cada género $50 \%$.

A su vez, este tipo de castigo debió ser considerado por los ideólogos de las visitas de idolatrías como eficiente, ello nos explica las sugerencias de Arriaga acerca de construir más cárceles en otras zonas de los Andes, puesto que, a juicio del jesuita, el único remedio para terminar con el arraigado mal era: "[...] la reclusión en Santa Cruz, que la temen grandemente [...] Y habrá de hacer necesario en cada obispado hacer otra, pues con buena traza no será dificultoso el sustentallos, y donde no hubiere casa donde esten reclusos, se podrian repartir en los conventos de religiosos $y$ hospitales y en otras casa de gente pía, donde los guarden, enseñen y sustenten" ${ }^{67}$.

${ }^{64} \mathrm{AAL}$, leg. V, exp. 2: "Causa de ydolatria contra los yndios ydolatras hechiceros del pueblo de señor San Francisco de Mangpas”, 1662.

${ }^{65}$ VillagómeZ, Pedro de, cit. (n. 21), p. 68.

${ }^{66}$ Barraza, Jacinto, Historia de las fundaciones de la Compañía de Jesús en el Perú (Copia dactilografiada en Biblioteca Nacional de Lima).

${ }^{67}$ Arriaga, Pablo de, cit. (n. 32), p. 110. 
El concepto de cárcel estaba en plena transformación modernizante, pues ya no sólo era para que los reos se arrepintieran y escarmentaran de sus delitos, o evitar que se ausentaran mientras pendía el juicio, sino que también con la reclusión se intentó contrarrestar el peligro que significaba la presencia de este tipo de delincuentes en los pueblos de indios, reeducarlos y de paso lograr un control social y religioso sobre los indígenas catalogados de peligrosos.

\section{Pena de prestación de Servicios a conventos u hospitales}

El sistema de penas aplicado por las visitas de idolatrías tuvo finalidades utilitaristas, en el sentido de que su imposición prestase algún servicio a la comunidad. Como hemos visto, tal es el caso de la pena de galeras impuesta por la Inquisición y extendida a los indios declarados idólatras.

Pero a su vez la Iglesia indiana creyó conveniente establecer otras penas cuya aplicación perseguía variados objetivos: sanción al delincuente por su actitud idolátrica; reparación del mal, mediante la ayuda que debía prestar el reo a la comunidad, y reevangelización del mismo. En buenas cuentas, estamos en presencia de una pena cuya finalidad, más que la represión, tuvo como propósito, por una parte, reeducar al hechor de la conducta alejada de la ortodoxia, con el fin de que se reincorporara al seno de la Iglesia, y por la otra, indemnizar a la comunidad por el quebrantamiento de la paz y orden social debido a su conducta idolátrica.

Tal es el caso de la sentencia condenatoria pronunciada por el visitador de idolatrías Juan Ignacio de Torres i Solis, quien sentenció a Agustin Ricapa: “[...] sobre ser embustero cerimoniero $i$ dar entender a otros yndios e indias con palabras supersticiosas que es adivino para que hagan lo que el dixere $i$ lo demas contenido en los autos. Dixo que atento a ser lo susodicho enbuste sin aver pacto ni concierto con el demonio le devia de condenar i condeno tan solamente a seis meses de servicio de los pobres del hospital de la misericordia desta dicha ciudad donde sea llebado para que cumpla en el dicho servicio [...]"68.

Cabe destacar que este tipo de pena, menos severa, pues no conllevaba en sí una denigración del delincuente, podía ser graduada. Esto es, si de los expedientes resultaba que el acusado había confesado y cooperado a esclarecer los hechos, se lo podía sancionar simplemente con la obligación de prestar servicios por un tiempo, el que podía ir de meses a años.

Lo anterior se ve claramente reflejado en la causa seguida por Juan Sarmiento de Vivero contra los nativos de Quinti, quienes son acusados y condenados por hechicerías, supersticiones y blasfemias. Las penas variaron de un reo a otro, según su grado de responsabilidad y participación en los delitos, como también conforme con su cooperación en el juicio. Así pues, a muchos de estos indígenas idólatras, y pese a la gravedad de sus delitos, se les impuso la pena de prestar servicios a la iglesia local una vez por semana, ello como premio a su buen comportamiento durante el juicio. Mientras que aquellos que no confesaron u omitieron antecedentes para

${ }^{68}$ AAL leg. IV, exp. 3: "Autos criminales seguidos contra Agustin Carvajal o Ricapa, indio natural de Huanuco", 1662. 
esclarecer y determinar los hechos vieron agravada la pena y complementada por otras más severas: "A don Pedro Solis [...] por dogmatista hechicero idolatra confesso y convicto le condeno a sien asotes sobre una bestia de albarada corosa cruz perpetua al cuello y la pena de destierro la conmuto en dos años de serbicio personal en barrer todos los sabados la iglesia de Quinti [...]. A Maria Guanico [...] por hechicera idolatra mingadora convicta i confesa la condeno a corosa cruz perpetua al cuello i la pena corporal se la conmuto por aber denunciado de otros en dos años de serbicio los sabados de ellos en barrer la iglesia del dicho pueblo [...]" ${ }^{69}$.

En el mismo sentido, a Maria Susa Ayala, calificada de contumaz, convicta y hechicera, entre otros cargos, se le condenó a ser paseada sobre una bestia por las calles del pueblo, con voz de pregonero que publicara sus delitos y dos años de destierro en la ciudad de Lima, los cuales debió cumplir en el hospital de los naturales prestando servicios ${ }^{70}$.

En otras palabras, cómo se graduaba esta pena dependía de si el reo había sido buen confesante o no. Así, en los casos en que el delincuente había tenido una actitud negativa hacia el tribunal, la pena se veía agravada en dos sentidos: por una parte, porque iba complementada con otras más severas, y por la otra, porque la prestación de servicios debía realizarla en Lima en el hospital de los naturales, viéndose desarraigado de su pueblo y comunidad.

Por el contrario, en el caso de aquellos que el tribunal calificaba de buenos confesantes, la prestación de servicios a la comunidad servía como atenuante de la responsabilidad y disminuía la pena, como acontece con varios indios del pueblo de Santa Catalina de Pimache, entre ellos: "[...] Francisca Quillay Tanta por la misma causa y teniendo con ella toda la misericordia por auer sido buena confesante la debo condenar a que salga en cuerpo a asistir en la iglesia y la sirua y a la doctrina con los muchachos en la yglesia deste pueblo tiempo dos años a disposición de su cura $[\ldots]^{\prime 71}$.

Ahora bien, esta pena, aunque con importantes transformaciones, se encontraba en estrecha relación con la pena de reclusión que imponía la Inquisición por la comisión de delitos menos graves. En efecto, la pena de reclusión impuesta por los inquisidores era una privación de libertad que se cumplía en un convento, hospital u otro establecimiento de beneficencia, lo que daba carácter de utilitarista

${ }^{69}$ AAL leg. IIA, exp. 6: "Sentencia que pronuncia el visitador bachiller Juan Sarmiento de Vivero en las causas que se fulminaron a varios indios del pueblo de Quinti, en orden a la idolatría y supersticiones”, 1660.

${ }^{70}$ AAL, leg. V, exp. 7: "Causa criminal contra Maria Susa Ayala, mercanchifle, acusada de inquietar a los hombres y comerciar con tierra, agua y hierbas que tienen virtud de ventura. Tambien son procesados, su compadre Sebastián Huata Quito por suersticioso, usar de venenos y haberse fugado del cepo donde estaban preso. Y el padre de este, Sebatian Quito el viejo por vivir apartado, ser hechicero al que consultaban para los casamientos y no saber los rudimentos de la doctrina cristiana”, 1662.

71 "Causa hecha a los yndios camachicos del pueblo de Santa Catalina de Pimachi anejo de la doctrina de San Pedro de Hacas por aver sacado los cuerpos de la yglesia y llevadolos a sus machayes y aver adorado ydolos y otros ritos y ceremonias antiguas", en Duviols, Pierre, Procesos y visitas de idolatrías, Cajatambo Siglo XVII (Lima, Pontificia Universidad Católica de Lima, 2003), p. 320. 
al castigo. En las sentencias emanadas de los visitadores de idolatrías no siempre la pena de prestar servicios conllevó una privación de libertad. Tal como se ha señalado, hubo idólatras a los que se les impuso la obligación de concurrir a la doctrina y ayudar al sacerdote una vez por semana, sin que ello constituyera límites para su circulación. Más aún, ello nos muestra que muchos de los condenados a prestar servicios continuaron viviendo junto a sus familias y realizando las labores que comúnmente ejecutaban, de tal forma que la pena inquisitorial se adecuó a la realidad indígena.

\section{Abjuración}

La pena de abjuración consistía en una detestación solemne y pública de la herejía o idolatría, la que se hacía bajo juramento, repudiando las falsas creencias y errores religiosos, cuestión que comprendía la reconciliación con la Iglesia y la absolución de la excomunión. En otras palabras, era el medio que tenía aquel que había incurrido en un error en la fe para volver a ser admitido en el seno de la Iglesia.

Para ello, quien abjuraba debía cumplir ciertas condiciones. Entre ellas: detestar el error en que se había incurrido, confesar tal error, realizar la profesión de la fe católica y jurar que no volvería a abandonar la fe. A su vez, se establecía que toda esta ceremonia debía quedar por escrito. Era, por tanto, un acto solemne, pues se hacía bajo juramento y además porque: "[...] los que abjuraron y de los que ellos supieren escribir lo firmaran con el juez, y el notario y testigos ${ }^{72 " .}$.

Asimismo, la abjuración que hacían los reos, se realizaba luego de leída la sentencia en el Auto de Fe. En consecuencia, la abjuración era una pena que tenía un carácter público, puesto que se realizaba en presencia de todo el pueblo. De ahí que también fuese una pena infamante, toda vez que involucraba la humillación de quien había sido sospechoso o condenado por idólatra.

La pena de abjuración era aplicada por la Inquisición desde la Edad Media y contemplaba variadas fórmulas ${ }^{73}$. Sin embargo, la abjuración aplicada por los visitadores de idolatrías no hizo tales disquisiciones. Muy por el contrario, hubo una fórmula única para todos los que estaban obligados a realizarla.

Su aplicación fue bastante frecuente debido, precisamente, al hecho de que todos los idólatras, e incluso los sospechosos de ser tales, estaban obligados a abjurar públicamente. De no hacerlo, no podían reconciliarse con la Iglesia y arriesgaban ser excomulgados.

La fórmula para llevarla a cabo se encontraba establecida en la Carta Pastoral del arzobispo Pedro de Villagómez, en virtud de la cual el visitador debía llamar a todos los acusados, quienes debían arrodillarse a la entrada de la iglesia para realizar la profesión de fe. Posterior a ello, el visitador con su pulgar les ponía la señal de la cruz en la frente de cada uno, y los invitaba a entrar en la iglesia.

A continuación el visitador pronunciaba una serie de oraciones, y nuevamente

\footnotetext{
${ }^{72}$ Villagómez, Pedro de, cit. (n. 21), p. 70.

${ }^{73}$ Para más detalles, véase: Eimeric, Nicolás, cit. (n. 31), p. 190 ss.; García-Molina Riquelme, Antonio, cit. (n. 23), pp. 551 ss.
} 
les hacía unas preguntas. Una vez contestadas, los empezaba a reconciliar. Los indios, de rodillas, hacían públicamente profesión de la fe: "[...] y la abjuración en voz alta en su lengua [...] Los indios que aqui estamos de rodillas, y cada uno de nosotros por si solo, decimos: que conocemos la verdadera, catolica y apostolica fe de Jesucristo nuestro señor y la profesamos de todo corazón, y por el contrario aborrecemos y maldecimos aqui públicamente todas las heregias que son contra de la dicha fey señaladamente las idolatrias errores y supersticiones del demonio en que avemos caido o de que asta aqui avemos estado infamados o sospechoso y sentimos y creemos los mismos que la Santa iglesia Romana cree y con la boca y corazon confesamos que creemos y tenemos la misma fe que ella tiene [...]"74.

Hecha la reconciliación, se los absolvía solemnemente de la excomunión.

\section{Consideraciones finales}

Al momento de organizarse la institucionalidad antiidolátrica en la diócesis de Lima se debió forzosamente tomar en consideración la realidad social, geográfica y cultural de la población indígena de las zonas rurales andinas y el Estatuto Protector, lo que implicó una transformación al sistema coactivo, que le dio características especiales y diferenciadas del sistema penal e inquisitorial del Antiguo Régimen adecuándose a la realidad andina; asimismo, anticipó las críticas públicas que se realizarían una centuria después en el mundo occidental al orden penal del Antiguo Régimen, estableciéndose un sistema punitivo protomederno o modernizante.

Lo anterior se refleja en las finalidades de la pena, pues no sólo tuvieron por fin reprimir y ejemplificar para provocar un impacto en la sociedad aplicada, por ejemplo, las penas infamantes, sino que además tuvieron por objeto reeducar y reformar al idólatra. Es decir, el sistema de castigo tuvo una intencionalidad represiva, pero también formativa. Ello se manifiesta claramente, por ejemplo, en la obligación que tuvieron algunos condenados de concurrir a la doctrina una determinada cantidad de días, o bien, de realizar trabajos para la comunidad.

Aunque lo más sorprendente fue la implementación de la cárcel de Santa Cruz en el Cercado de Lima. Ella se ideó para que todos los considerados peligrosos para la cristiandad estuviesen allí recluidos de por vida, pero con la variante de que además fuesen convertidos y reformados para lograr su salvación.

Considerar el encierro del delincuente como una alternativa coactiva, evidencia un incipiente debate antropológico jurídico que hizo el cuerpo social referente a la época de la aplicación de penas humillantes o infamantes a los indígenas. En otras palabras, es posible sostener que se estaba iniciando una reflexión relativa al sistema correccional penitenciario.

Además, la pena carcelaria significó lograr el control social sobre aquellos que las autoridades limeñas consideraban el mayor peligro para la ortodoxia religiosa -los dogmatizadores y sacerdotes de la idolatría-, puesto que se los alejaba de las comunidades, perdiendo así su influjo social, político y religioso.

${ }^{74}$ VillagómeZ, Pedro de, cit. (n. 21), p. 70. 
Tales objetivos de reeducar y reformar al hombre constituyeron un salto modernizador, que fue posible por la necesidad de observar el Estatuto Protector. Ya no era posible aplicar el sistema punitivo tal como estaba justificado jurídica y teológicamente. En efecto, debieron introducir nuevas finalidades y tipos de penas que se adaptaran a la población a la que iba dirigida. Incluso, pese al celo que tuvo la Iglesia en perseguir y terminar con las idolatrías y todo aquello que pudiese poner en jaque la ortodoxia, se vio forzada a flexibilizar su postura respecto a las sanciones y castigos, atenuando el carácter represivo e infamante que la caracterizaba. Evitaban con esto también la Iglesia y la Corona quebrantar el primer deber que tenían: evangelizar y proteger a los indígenas, para así ganar más almas para su causa: la salvación.

[Recibido el 11 y aprobado el 21 de agosto de 2010].

\section{BiBLIOGRAFÍA}

Araya, Alejandra, Ociosos, vagabundos y malentretenidos (Santiago, DIBAM, Centro de Investigaciones Barros Arana, Lom, 1999).

Arriaga, Pablo de, Extirpación de la Idolatría en el Perú (Cuzco, Centro de Estudios Regionales Andinos Bartolomé de las Casas, 1999).

Barraza, Jacinto, Historia de las fundaciones de la Compañía de Jesús en el Perú (Copia dactilografiada en Biblioteca Nacional de Lima).

Borges Morán, Pedro, Métodos misionales en la cristianización de América. Siglo XVI (Madrid, Consejo Superior de Investigaciones Científicas, 1940).

Covarrubias Horozco, Sebastián, Tesoro de la lengua castellana o española (Madrid, Luis Sánchez, 1611).

Duviols, Pierre, La lutte contre les religions autochtones dans le Pérou colonial (Paris, Institut Français d'Etudes Andines, 1971).

Duviols, Pierre, Procesos y visitas de idolatrias, Cajatambo Siglo XVII (Lima, Pontificia Universidad Católica de Lima, 2003).

EImeric, Nicolau, El manual de los inquisidores (Barcelona, Muchnik Editores, 1983).

Foucault, Michel, Vigilar y castigar. Nacimiento de la prisión (Buenos Aires, Siglo Veintiuno, 2004).

García Marín, José María, Magia e Inquisición. Derecho penal y procedimiento inquisitorial en el siglo XVII, en Escudero, Antonio (editor), Perfiles jurídicos de la Inquisición Española (Madrid, Universidad Complutense, 1992).

García-Molina Riquelme, Antonio, El régimen de penas y penitencias en el Tribunal de la Inquisición de México (México, Universidad Nacional Autónoma de México, 1999).

LEA, Henry, Historia de la Inquisición Española (Madrid, Fundación Universitaria Española, 1983), II.

LEÓN, Marco Antonio, Encierro y corrección. La configuración de un sistema de prisiones en Chile. (1800.1911) (Santiago, Universidad Central, 2003).

Maqueda Abreu, Consuelo, El auto de fe, en Escudero, Antonio (editor), Perfiles jurídicos de la Inquisición Española (Madrid, Universidad Complutense, 1992). 
MaynTZ, Renate, Sociología de la organización (Madrid, Alianza, 1972).

Millar, René, Inquisición y sociedad en el virreinato peruano (Santiago, Pontificia Universidad Católica de Chile, 1997).

Solórzano y Pereira, Juan de, Política Indiana (Madrid, Biblioteca de Autores Españoles, 1972), II.

Tomás y Valiente, Francisco, El Derecho penal en la Monarquía absoluta. Siglo XVI, XVII y XVIII (Madrid, Tecnos, 1969).

Vargas Ugarte, Rubén, Historia eclesiástica del Perú (Burgos, 1959), II.

VIllagómez, Pedro de, Carta Pastoral de exhortación e instrucción acerca de las idolatrías de los indios del arzobispado de Lima (Lima, 1649). 
